\title{
Mental Emotional Disorder due to Inhalant in Medan
}

\author{
Rinaldi Fajri*(D), Mustafa M. Amin (D), Elmeida Effendy (D) \\ Department of Psychiatry, Faculty of Medicine, Universitas Sumatera Utara, Medan, Indonesia
}

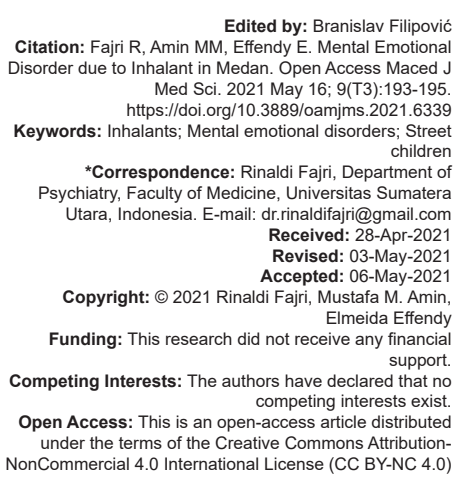

Edited by: Branislav Filipovic Citation: Fajri R, Amin MM, Effendy E. Mental Emotiona Disorder due to Inhalant in Medan. Open Access Maced Med Sci. 2021 May 16; 9(T3): 193-195. Keywords: Inhalants; Mental emotional disorders: Stre children Pychiatry, Faculty of Medicine, Universitas Sumatera Utara, Indonesia. E-mail: dr.rinaldifaji@@gmail.com Received: 28-Apr-202 Revised: 03-May-2021
Accepted: 06-May-2021 Copyright: ๑ 2021 Rinaldi Fajri, Mustafa M. Amin, Funding: This research did not receive any financial Competing Interests: The authors have declared that no competing interests exist. Open Access: This is an open-access article distribute
under the terms of the Creative Commons AtributionNonCommercial 4.0 International License (CC BY-NC 4.0)

\begin{abstract}
BACKGROUND: Inhalants, also known as volatile substances or solvents, are volatile hydrocarbons, which become gases at room temperature. Inhalants are substances commonly used by homeless teenagers. The effects of this substance vary including stamina enhancing effect, self-resistance, agitation, paranoid, hallucinations, and chest pain. We expect that this case report is able to show how vulnerable teens are to become users of illegal substance, such as inhalants, particularly those who come from low socio-economical background.
\end{abstract}

CASE REPORT: Mental emotional disorders are commonly found among a 14-18-year-old man who engages in glue sniffing that may end up with jail. Most of the cases in Medan were found in children from broken home families or with low financial background, dropping out of school, and those suffering from bullying. Therefore, we particularly report a case of a 14-year-old boy who uses inhalant (glue) in Medan.

CONCLUSION: Several studies show that the use of inhalants in street children is quite high.

\section{Introduction}

Volatile hydrocarbons, which become gases at room temperature, are inhalants, also called volatile substances or solvents. Such compounds are used as solvents, propellants, thinners, and fuels in many household goods. One such volatile hydrocarbon, toluene, for instance, is a main ingredient in certain glues [1].

Individuals, especially adolescents, inhale these products for their intoxicating effects. Among US eighth-graders, inhalants are among the most commonly used illicit drugs, with about $11 \%$ reporting lifetime use, a prevalence rate higher than those of all other illicit drugs except marijuana. However, with increasing age, the prevalence of past-year inhalant use declines; most adolescents discontinue their inhalant use and few people ever meet criteria for inhalant use disorder. Inhalants, however, are correlated with several issues, including behavioral disorder, non-inhalant SUDs, mood, anxiety and personality disorders, suicidality, and a history of physical/sexual violence and neglect victimization; early inhalant usage can signify a lifelong issue with outsourcing habits, pursuing creativity, impulsivity, and risk-taking propensity for some adolescents [1].

We wrote this article with the aim of showing how vulnerable teens are to become users of illegal substance, such as inhalants, particularly those who come from low socio-economical background.

\section{Case Report}

A 14-year-old boy is reported to experience a temper tantrum, talking by himself, and headache that have been occurring for the last 2 months. He admits of hearing voices and even is able to talk back to those voices. He is troubled with difficulty of sleeping, prefers to seclude himself, and no longer grooms himself well, becomes less involve in any activities at home that previously routinely performed. This last 1 year, he is seen to be along with his friends (mostly are vagrant teens) and earns money from selling newspaper and busking. He is often engaged to volatile substance abuse, such as glue sniffing that he buys from nearby kiosk. His parents are divorced a year earlier and the father has already remarried. The boy ended up living with his mother and had to stop going to school at the fifth grade to help earning the bread as the financial situation in the family had become even more unfavorable. His mother, in the other hand, has to do two different jobs each day, as street cleaner, and house keeper, to support the family. The boy has 4 younger siblings. He is also often seen to fight with 
other vagrant kids and involves in robbery, along with his friends, in a local market not far from his house. History of current medical disorders or any medical issues within pregnancy period and childhood are not found. He admits to never attempt on suicide. History of having caught by the police was also found.

According to the psychiatric interview, he was found to exhibit inappropriate affect, dysphoric mood, and showed disturbed reality test. Psychosis and auditory hallucination were found. In the other hand, his orientation was found to be undisturbed that he is completely conscious, but we found that his concentration and calculation skill were disturbed. Long and midterm memory were fine, but recall of sudden memory was disturbed. General knowledge and abstract were fine, insight was found to be at level 1 and judgment test was fine, while social judgment test was interrupted.

We found no abnormalities from physical examination, vital signs and neurologic signs were also within normal limits. Therefore, the boy was diagnosed with mental and behavior disorders related to volatile substance abuse. The boy is then prescribed with Risperidone $2 \times 1 \mathrm{mg} /$ day/oral.

\section{Discussion}

Adolescent inhalant use is a serious public health concern that impacts antisocial youth overwhelmingly. Antisocial youth prevalence rates are close to $40 \%$, compared to nearly $8.8 \%$ of youth in the general population. Inhalants are described by the National Institute on Drug Abuse as "volatile substances that produce chemical vapors that can be inhaled to induce a psychoactive or mind-altering effect." Glue, paint, gasoline, solvents, whipped cream dispensers, and nail polish remover are examples of inhalants. The symptoms of inhalant intoxication last just a few minutes, and include slurred voice, ataxia, euphoria, and dizziness, similar to alcohol. Inhalant use can have deleterious health consequences including brain damage, heart irregularities, optic nerve damage, hearing loss, liver damage, muscle atrophy, and death. Population-based studies have found that inhalant use is associated with mental illnesses, criminal activity, and use of multiple drugs [2].

Inhalant use has been listed among the most prevalent forms of adolescent drug use by nationally representative surveys for more than 30 years. Results from the 2006 Tracking the Future study, for instance, found that $16.1 \%$ of U.S. $8^{\text {th }}$ graders used inhalants, compared with $15.7 \%$ who used marijuana/ hashish, and $7.3 \%, 3.4 \%, 3.4 \%$, and $1.4 \%$ who used amphetamines, hallucinogens, cocaine, and heroin, respectively. Recently, Wu et al. reported that inhalants based on data from the National Substance Use and
Health Survey were used by two million 12-17-yearolds in the United States [3].

It is suspected that inhalants such as toluene are direct dopamine releasers in the nucleus accumbent. "Bath salts" are synthetic stimulants that include, but may not include mephedrone or methylene, the active ingredient methylenedioxypyrovalerone (MDPV). They are also referred to as "plant food" and can have stimulating effects like most stimulants, but they also cause anxiety, paranoia, hallucinations, suicidality, and chest pain [4].

Based on the DSM-5 diagnostic criteria for inhalant use disorders:

A. A problematic pattern of use of a hydrocarbonbased inhalant substance leading to clinically significant impairment or distress, as manifested by at least two of the following, occurring within a 12-month period:

1. The inhalant substance is often taken in larger amounts or over a longer period than was intended.

2. There is a persistent desire or unsuccessful efforts to cut down or control use of the inhalant substance.

3. A great deal of time is spent in activities necessary to obtain the inhalant substance, use it, or recover from its effects.

4. Craving, or a strong desire or urge to use the inhalant substance.

5. Recurrent use of the inhalant substance resulting in a failure to fulfill major role obligations at work, school, or home.

6. Continued use of the inhalant substance despite having persistent or recurrent social or interpersonal problems caused or exacerbated by the effects of its use.

7. Importantsocial, occupational, or recreational activities are given up or reduced because of use of the inhalant substance.

8. Recurrent use of the inhalant substance in situations in which it is physically hazardous.

9. Use of the inhalant substance is continued despite knowledge of having a persistent or recurrent physical or psychological problem that is likely to have been caused or exacerbated by the substance.

10. Tolerance, as defined by either of the following:

a. A need for markedly increased amounts of the inhalant substance to achieve intoxication or desired effect.

b. A markedly diminished effect with continued use of the same amount of the inhalant substance [5].

In 2015, Dhawan et al. reported that the most prevalent and common substance used by street children was inhalant use by teenage drug users. 
Results show that in the past month, about $96 \%$ of the sample used these volatile substances on a regular basis; with $83 \%$ reporting the use of eraser fluids, a typewriting correction fluid containing toluene and highly preferred due to its euphoric effect, inexpensiveness, and easy availability. Studies suggest that inhalants are often the first type of teenage drugs to be abused and therefore represent a 1.5-year gateway drug preceding cigarettes [6], [7].

Risperidone is a second generation antipsychotic introduced after clozapine in the United States. This drug blocks D2 receptors. This drug also has an antagonistic effect on the 5-HT2 receptor and possibly also on the $5-\mathrm{HT} 1$ receptor. Risperidone is an $\alpha 1$ and $\alpha 2$ adrenergic antagonist and histamine receptor. The recommended initial dose of risperidone is $1 \mathrm{mg} /$ day in divided doses, raised $1 \mathrm{mg} /$ day until the desired effect is obtained. The maximum dose is $16 \mathrm{mg} /$ day, the maximum effect is usually seen in a dose range of 4-8 mg/day/oral [8].

\section{Conclusion}

Several studies show that the use of inhalants in street children is quite high. We suggest the role of various parties to reduce the incidence of inhalant use among vagrant teens in Medan.

\section{References}

1. Howard MO, Bowen SE, Garland EL. Kaplan and Sadock's Comprehensive Textbook of Psychiatry. $10^{\text {th }}$ ed. Philadelphia, PA: Lippincott Williams \& Wilkins; 2017. p. 3420-1.

2. Snyder SM, Howard MO. Patterns of inhalant use among incarcerated youth. PLoS One. 2015;10(9):e0135303. https:// doi.org/10.1371/journal.pone.0135303

PMid:26333159

3. Howard MO, Perron BE. A survey of inhalant use disorders among delinquent youth: Prevalence, clinical features, and latent structure of DSM-IV diagnostic criteria. BMC Psychiatry. 2009;9(1):8. https://doi.org/10.1186/1471-244x-9-8 PMid:19267939

4. Stahl SM. Stahl's Essential Psychopharmacology Neuroscientific Basis and Practical Applications. $4^{\text {th }}$ ed. Cambridge: Cambridge University Press; 2013. p. 902.

5. American Psychiatric Association. Diagnostic and Statistical Manual of Mental Disorders (DSM-5®). Virginia, United States: American Psychiatric Association; 2013. p. 533-4.

6. Embleton L, Mwangi A, Vreeman R, Ayuku D, Braitstein P. The epidemiology of substance use among street children in resourceconstrained settings: A systematic review and meta-analysis. Addiction. 2013;108(10):1722-33. https://doi.org/10.1111/add.12252 PMid:23844822

7. Dhawan A, Chopra A, Ambekar A, Ray R. Treatment seeking behavior of inhalant using street children: Are we prepared to meet their treatment needs. Indian J Psychol Med. 2015;37(3):282-7. https://doi.org/10.4103/0253-7176.162918 PMid:26664076

8. Schatzberg A, DeBattista C. Manual of Clinical Psychopharmacology. Philadelphia, PA: American Psychiatric Publishing; 2015. p. 411-30 